\title{
A Comparison of Control Methods of Air Pollution in London and Beijing
}

\author{
D. Tang
}

\begin{abstract}
In 1952, London was enveloped by poisonous smog and caused 12,000 deaths, which triggered the British government established comprehensive air pollution governance. In Beijing, people have experienced unhealthy levels of air pollution for over 20 years. To improve Beijing air pollution governance, the study examines the air pollution characteristics of Beijing and utilises a benchmarking approach to identify where improvements are warranted. London is selected as a benchmarking partner to examine how it achieved its outstanding performance on air pollution mitigation. The benchmark criteria across pollution characteristics and levels, regulations, public participation, promotion of alternative energy are applied in comparing the performance of air pollution mitigation in both London and Beijing. By working out the gaps between London and Beijing, the weaknesses and recommendations in air pollution governance in Beijing can be identified, including upgrading air quality monitoring network, improving air pollution legislative framework, establishing new administrative departments for efficient law enforcement and distinct liability, raising the standards for vehicles and fuels, promoting public participation and low-carbon life.
\end{abstract}

Index Terms-Air pollution governance, benchmarking, legislative framework, public participation.

\section{INTRODUCTION}

Air pollution is a major problem throughout much of East Asia and Southeast Asia. It is estimated globally that there were about 7 million deaths caused by air pollution exposure in 2012. Air pollution has become one of the greatest health risks at present [1].

Due to reform and opening-up of the country, China's economic development has grown in leaps and bounds. However, with the rapid economic growth, the environment has deteriorated. Air pollution is currently one of the biggest problems in China. It is reported that 340,100 to 490,900 premature deaths every year have been linked to air pollution [2]. Beijing, the capital of China, has experienced a series of severe air pollution events over the last twenty years, which poses a significant threat to human health. Fine particulate matter of 2.5 micrometres in size $\left(\mathrm{PM}_{2.5}\right)$ is the main pollutant in these pollution events. Therefore, there is a significant need to actively manage air pollution in order to avoid further continuing serious health issues.

Many cities throughout the world have adopted effective means to mitigate air pollution and many have seen a dramatic improvement. London experienced a major Black

Manuscript received August 30, 2018; revised February 13, 2019.

D. Tang is with the College of Humanities, Arts and Social Sciences, Flinders University, GPO Box 2100, Adelaide 5001, South Australia, Australia (e-mail: henrytang0910@gmail.com).
Smog episode during the 1950s and Britain subsequently enacted a range of controls which have seen pollution levels reduce significantly and a subsequent improvement in associated health outcomes, particularly in the capital city.

London was frequently enveloped by poisonous smog, however during the winter of 1952, there was a particularly bad smog event. Subsequently, about 4,000 people were killed by the smog, and there were 8,000 people living in London who died subsequently due to delayed effects of the smog [3]. As a consequence of the smog, the national government enacted a series of laws that resulted in improvements to local areas such as London. Williams [4] examined that the first Clean Air Act formulated and enacted by the British government in 1956 has been highly valued as one of the most important milestones for the modern development of legislative frameworks regarding air pollution mitigation. Dockery [5] evaluated that Clean Air Act 1956 equipped the modern environmental movement with great motivation, and legislative frameworks regarding governing atmospheric environment were gradually established. The Clean Air Act 1968 and Clean Air Act 1993 and other laws and policies continuously improved air quality governance, which consolidated air pollution mitigation in London. Elsom and Longhurst [6] described that the National Air Quality Strategy set up several mitigation targets, outlined a more detailed policy framework and strengthened financial support which include market-based instruments (MBIs) and decentralisation.

Beijing has experienced several heavy $\mathrm{PM}_{2.5}$ pollution events for over twenty years. The sources of $\mathrm{PM}_{2.5}$ mainly comes from both heavy industry and transportation. Nationally, one tenth of thermal power plants are located in the Beijing-Tianjin-Hebei region [7]. It is reported that there were 5.63 million vehicles in Beijing by the end of 2015, and part of them is with poor emission standards, which means that their exhaust fumes contain excessive $\mathrm{SO}_{2}, \mathrm{NO}_{2}$ and $\mathrm{PM}_{2.5}$ [8]. Although there has a series of air pollution mitigation policy been made by the central and local governments, the concentration of $\mathrm{PM}_{2.5}$ in Beijing remains at unhealthy levels. He et al. [9] examined that The Environmental Protection Law played a role of general guidance for reducing various sources of pollution, which means the content has less explanation and details of $\mathrm{PM}_{2.5}$ mitigation management. Zhang et al. [10] pointed out that the revision of the Law on Air Pollution Prevention and Control 2016 provided a specific policy regarding how to deal with air pollution throughout the country. Zhuang et al. [11] conceded that there were less effective long-term legislation frameworks and policies for $\mathrm{PM}_{2.5}$ from 2000 to 2012, which led to a serious air quality crisis. 
Therefore, the study aims to examine the air pollution characteristics of Beijing and utilises a benchmarking approach to identify where improvements are warranted. It will examine how London achieved their high-performance levels and use this information to suggest improvements in the air pollution management for Beijing. The objectives of this study cover five areas. These are, 1) to gain an overall picture of air pollution in London and Beijing; 2) to recognise and identify the advantages of air pollution mitigation approaches in London; 3 ) to identify and understand the main problems of air pollution mitigation in Beijing; 4) to develop a benchmarking analysis process as an analytical framework to identify best practice; 5) to identify areas for development of an improved Beijing air pollution mitigation plan. The expected impacts of the study are to cultivate a systematic air pollution mitigation framework which can be adopted in Beijing and other regions in China especially those near the city.

\section{ANALYTICAL FRAMEWORK}

Benchmarking analysis allows researchers to compare specific cases with best practical examples, which is the most effective approach that can help identify gaps, understand disadvantages and adapt excellent practices from other outstanding examples [12].

\section{A. Analytical Framework}

According to MacKerron and Mourato [13], one of the best air quality mitigation countries is Britain. London government made tremendous contributions to implementing the controls of air pollution after experiencing a wide range of disastrous air pollution events. As a result, air quality in London largely remains at a healthy level. Compared with London, Beijing has many similarities, such as a high population density urban area and rapid industrial expansion. Therefore, London is selected as a benchmarking city in helping to facilitate improved air pollution mitigation in Beijing. The actions taken by authorities in London can facilitate studying and exploring more advanced urban air pollution mitigation which can then be applied in Beijing. The daily $\mathrm{PM}_{2.5}$ index for both London and Beijing, and air pollution mitigation governance legislation, policies and regulations of air pollution mitigation in London and Beijing were used in the analysis.

\section{B. Benchmark Criteria}

A range of criteria is developed for the benchmarking process. These criteria cover both pollutant levels and a range of policy, legislative and regulatory components. Overall, 11 criteria are used, and the following sections briefly outline each criterion and how it is applied in the analysis.

\section{1) Air quality monitoring network (BM1)}

The air quality monitoring network, identifies the number of monitoring stations and their distribution.

Benchmarks:

- Widely available: A large number of monitoring stations and appropriate distribution.

- Limited: Few monitoring stations and inappropriate distribution.
- Absent: No monitoring network.

\section{2) Stringent PM2.5 requirement (BM2)}

Stringent $\mathrm{PM}_{2.5}$ Requirement, which means higher and stricter requirements for $\mathrm{PM}_{2.5}$ levels.

Benchmarks:

- Yes: Annual value $\leq 25 \mu \mathrm{g} / \mathrm{m}^{3}$

- No: Annual value $\leq 60 \mu \mathrm{g} / \mathrm{m}^{3}$

3) Unambiguous legal provisions (BM3)

Unambiguous legal provisions, which are defined in legislation as explanatory, detailed and operable provisions.

Benchmarks:

- Widely available: All articles in laws, policies and regulations related to the environment have sufficient explanation, detail and operability.

- Limited: A number of articles in laws, policies and regulations related to the environment have less explanation, detail and operability.

- Absent: Articles in laws, policies and regulations related to the environment have no explanation, detail or operability.

\section{4) Standards for vehicles (BM4)}

Standards for vehicles, identifies and outlines the requirements for vehicle emissions. Normally, within the European Union, countries implement EURO standards from I to VI. In China, the range of standards is from National I to $\mathrm{V}$. I is the lowest requirement VI is the highest.

Benchmarks:

- High: More stringent requirements for vehicle emissions.

- Low: Less stringent requirements for vehicle emissions.

\section{5) Distinct legal liability (BM5)}

Distinct legal liability, which means departments related to environmental protection play specifically different roles and have corresponding responsibilities for environmental issues.

Benchmarks:

- Widely available: Departments understand their own responsibilities, no mutually making excuses and bureaucracy.

- Limited: Improper roles, blurred responsibility and absent functions to some extent.

\section{6) Strict punitive measures (BM6)}

Strict punitive measures, which represent the range of measures used to punish polluters. For example, the use of fines and incarceration of offenders.

Benchmarks:

- Widely available: Multiple ways to punish offenders.

- Limited: Few ways to punish offenders.

- Absent: No precise ways to punish offenders.

\section{7) Congestion Charging scheme (BM7)}

The congestion charging scheme, provides a means to reduce vehicle movement in cities. For example, London has instigated a congestion tax to reduce the number of vehicles driving through central London. Currently the charge is $£ 11.5$ per day.

Benchmarks:

- Present: Detailed charging mechanism

- Absent: No charge

8) Open and transparent air pollution information 


\section{available to the public (BM8)}

Open and transparent air pollution information freely available to the public. This can facilitate people altering their activities on high pollution days.

Benchmarks:

- Widely available: Information available in multiple ways, such as newspapers, television programs, radios, posters and smart phone applications.

- Limited: Some of the information is made available to the public.

- Absent: No publicly available information.

9) Active public participation (BM9)

Active public participation, indicates where people participate proactively in environment protection activities, such as ride sharing.

Benchmarks:

- High: The governments at all levels encourage people to get involved in environmental protection movements. People are also willing to participate in environment protection activities.

- Low: The governments undertake a lower level of practical action to support environmental protection activities. People have less environment protection awareness.

- Absent: No actions are taken to promote environmental protection and people have little or no environment protection awareness.

\section{0) Promotion of clean energy vehicles (BM10)}

Promotion of clean energy vehicles, where the use of clean energy vehicles and infrastructure is supported by policies. For example, subsidies are available for alternative fuel and public charging sites for electric vehicles are in place.

Benchmark:

- Widely available: Clean energy vehicles are used for both public transport and private purposes. The governments formulate policy to support using clean energy vehicles.

- Limited: The governments promote clean energy vehicles to some extent.

- Absent: No promotion of clean energy vehicles in the public or private sector.

\section{1) Development of energy efficient buildings (BM11)}

Development of energy efficient buildings is encouraged and supported by regulations and subsidies.

Benchmarks:

- Widely available: People are willing to live in energy efficient buildings. Supportive regulations are available.

- Limited: Energy efficient buildings are limitedly developed due to financial and cultural factors.

- Absent: No promotion of energy efficient buildings.

\section{RESULTS}

\section{A. The Policy Framework for Britain}

As a pioneer of modern atmospheric pollution mitigation, the British government made tremendous efforts to manage and improve its worsening air quality in the last century and set a good example. Air pollution management in Britain can be divided into three phases, the preparation phase (1953-1960), the reduction phase (1960-1980), and the stable phase (1980-present). It can be observed that changes and trends in concentration of the major pollutants have responded to ongoing mitigation policies implemented over the last 60 years.

\section{1) Preparation phase}

In the preparation phase, the Beaver Committee was established in 1953 and published a report on the Great Smog. The report thoroughly investigated the reasons for the smog and made proposals on atmospheric pollution mitigation [14]. At its core the Great Smog was caused by extremely high concentrations of $\mathrm{SO}_{2}$ and particulate matter from the burning of sulphurous coal. Subsequently, the Clean Air Act was issued in 1956, which laid the foundations for progress on environment protection [15]. In this Act, there were six measures to mitigate air pollution. Firstly, the Act prohibited any black smoke emissions from a wide range of industries. At the same time, existing furnaces were required to have filters and new furnaces must be smokeless. Additionally, the requirements for grit and dust emissions from furnaces were tightly regulated. Secondly, the minimum height of chimneys was tightly constrained by the Act. Thirdly, smoke control areas were delineated in terms of industrial distribution. Fourthly, the Act positively encouraged citizens to burn cleaner energy sources instead of coal by providing subsidies for heating. Fifthly, in the Act, a specific department, the Clean Air Council, was proposed to be established, and the duties of the Council included mitigation policy formulation, supervision on implementation, guidelines on mitigating management, and the power of administration and penalty. Finally, the Act outlined the penalties (ten pounds, one hundred pounds or imprisonment) for offences under various situations [16].

\section{2) Reduction phase}

In the reduction phase, the concentration of pollutants was reduced spectacularly. The concentration of $\mathrm{SO}_{2}$ and black smoke decreased from $318 \mu \mathrm{g} / \mathrm{m}^{3}$ and $158 \mu \mathrm{g} / \mathrm{m}^{3}$ in 1960 to $57 \mu \mathrm{g} / \mathrm{m}^{3}$ and $19 \mu \mathrm{g} / \mathrm{m}^{3}$ in 1980 respectively, a decrease off $82.1 \%$ and $88.0 \%$ respectively [17].

The Clean Air Act was revised and expanded in 1968. In the Clean Air Act 1968, the Clean Air Council was further empowered to manage emissions controls. The Council was able to directly require local governments to delineate smokeless zones and to directly regulate new emission limit values for grit and dust from furnaces. The Act required the resetting of the height and location of chimneys for sufficient dispersion of emissions. Additionally, the Act also intensively supervised the sale of various fuels and prohibited any fuel sale without smoke control zones [18].

\section{3) Stable phase}

In the stable phase, air pollution mitigation governance was consolidated by comprehensive legislative framework. The Motor Fuel Regulation and The Road Vehicles Regulation required the limitation of the maximum content of lead in oil $(0.4 \mathrm{~g} / \mathrm{L})$, and added carbon monoxide and carbon monoxide standards to be included in the Ministry of Transport (MOT) test for petrol cars and light trucks. 
Secondly, the Air Quality Standards were issued in 1989, which set limit value $\left(80 \mu \mathrm{g} / \mathrm{m}^{3}\right)$ and guide value (40 to 60 $\mu \mathrm{g} / \mathrm{m}^{3}$ ) for $\mathrm{SO}_{2}$ and Suspended particulate.

The Environment Protection Act was published in 1990 and introduced integrated pollution and control (IPC). Additionally, the Best Available Technology Not Entailing Excessive Costs (BATNEEC) was also introduced by the Act, and it took technology and finance into consideration for making regulatory decisions [19]. The Act required that the production processes which would produce pollutants must apply to BATNEEC to control the pollution. Moreover, the Act decentralised to local governments to manage less hazardous air pollution issues.

The Clean Air Act was revised in 1993, and as the continuation of the Clean Air Acts 1956 and 1968, the new Clean Air Act consolidated the previous two Acts. Meanwhile, the new Act added regulations about engine fuels, and the sulphur content of oil fuels for furnaces. Moreover, the Act involved research and publicity. To be specific, the Act required local authorities to investigate the problems of air pollution, publish the information concerning the problems, and undertake lectures and discussions about the problems [20].

The Environmental Act was released in 1995 and instigated some new measures to manage air pollution. The Act required establishment of a new administrative department to cope with environmental issues. Moreover, the Act required the Secretary of State to formulate and publish a national strategy regarding air quality management. Additionally, local authorities were required to regularly review air. If air quality cannot reach the standards, the local governments must identify the issues. Based on results of their air quality reviews, the local authorities were required to take responsibility for air quality management area designation and formulate rectification plans. The local authorities were also required to supervise and revise the rectification plans from time to time when needed [21].

The National Air Quality Strategy 1997 was introduced by the Environmental Act 1995. The overall aim of the Strategy was to establish standards based on the Expert Panel on Air Quality Standards (EPAQS), the European Union (EU) Air Quality Directive and the World Health Organisation (WHO), and to achieve air quality objectives for eight air pollutants across the UK by 2005. The subsequent Strategy 2000 and Strategy 2007 were issued for more rigorous standards and objectives. A $\mathrm{PM}_{2.5}$ reduction plan was introduced by Strategy 2007 and the concentration of $\mathrm{PM}_{2.5}$ was capped at $25 \mu \mathrm{g} / \mathrm{m}^{3}$ [22]. The other main policy in Strategy 1997 is Local Air Quality Management (LAQM). Under this scheme, all local governments have to investigate and assess the level of air quality in their areas. When the LAQM is identified, the local government must prepare an action plan to improve air quality to meet the National Air Quality Strategy objectives.

The Pollution Prevention and Control Act 1999 introduced Integrated Pollution Prevention and Control (IPPC) from EU Directive 96/61/EC [23]. Under the IPPC, operators were required to apply Best Available Techniques (BAT), which are similar to the idea of BATNEEC, to conduct manufacturing [19].

During the $21^{\text {st }}$ century, London has gradually established a further series of implementations to manage local air quality. According to the Mayor's Air Quality Strategy [24], industrial pollution has not been the major contributor to poor air quality since the 1970s. In London, for example, roughly $80 \% \mathrm{PM}_{2.5}$ comes from road transport, while industrial and commercial contributions accounted for $20 \%$ in 2008. Therefore, the London Authority has begun to take actions regarding $\mathrm{PM}_{2.5}$ and other pollutants. Firstly, the London Authority has taken actions on transport systems, which include:

- Promoting public transport, upgrading diesel-electric hybrid buses, constructing cycling and walking infrastructure, and developing bicycle sharing for smarter travel.

- Encouraging electric or low emission cars.

- Maintaining roads in good condition to mitigate dust and improve traffic management for smoothing traffic.

- Retaining the Central London Congestion Charging Scheme.

Moreover, the Strategy also contributes to non-transport air pollution mitigation including reducing emissions from construction and demolition sites, developing energy efficient buildings, upgrading energy supply and improving public areas.

\section{B. The Policy Framework for China}

As the capital of China, Beijing has been applying these national air pollution mitigation policies to reduce local pollution levels. The Environmental Protection Law is the first overall law regarding environmental protection and was implemented in 1979 and revised in 1989 and 2015. The Law, in the original version, outlined the basic guide and summarised general implementations for environmental protection. The subsequent version, in 1989, added an environmental impact assessment (EIA) requirement [25]. The latest version, revised in 2015, provided more comprehensive guidance. Firstly, tighter EIA requirement has been set up. Secondly, information disclosure is written into the Law, and any offender will be published. Meanwhile, public litigation is also written in, and this means the public have more opportunities to participate in pollution mitigation. In addition, the Law suggests that environmental protection awareness should be written into compulsory education textbooks [26].

The Chinese government formulated its Ambient Air Quality Standard (GB3095-1996) in 1996 (Table I). The Standard mainly focused on three-level areas designation, and the index of hourly, daily and annual mean concentration of ten pollutants. Areas were basically divided into nature reserves and scenic spots (Level 1), residential and commercial areas and general industrial areas (Level 2), and specific industrial areas (Level 3). The Standard (GB 3095-2012) was revised in 2012 and implemented in 2016 (Table II). The latest Standard modifies the three-level areas to two-level areas (Level 3 is incorporated into Level 2) and adds a $\mathrm{PM}_{2.5}$ index and modifies the concentration of ten pollutants.

The Law on Air Pollution Prevention and Control was issued in 2000 and focused on vehicle exhaust fumes, dust and odour pollutants. The regulations also outlined the 
actions which needed to be taken regarding heavy air pollution from industry [27]. The Law was revised in 2015 and implemented in 2016.

The Law developed inter-regional coordination and joint management, and it also promoted and encouraged technology measures to mitigate $\mathrm{PM}_{2.5}$. Moreover, the Law increased punishment. For example, the Law cancelled the stipulation for a fine to "not exceed put actual amount $¥ 500,000$ (about AU\$100,000)", and revised criminal liability. The Law also required the improvement of fuel oil quality because in Beijing, for example, car emissions contribute $31 \%$ to $\mathrm{PM}_{2.5}$ [28].

TABLE I: SUMMARY OF AMBIENT AIR QUALITY STANDARDS (GB3095-1996)

\begin{tabular}{|c|c|c|c|c|c|}
\hline POLLUTANT & \multirow{2}{*}{ Time } & \multicolumn{3}{|c|}{ Values of concentration } & \multirow{2}{*}{ Unit } \\
\cline { 3 - 5 } & & L1 L2 L3 & \multirow{2}{*}{$\mathrm{mg} / \mathrm{m}^{3}$} \\
\hline SO2 & Annual & 0.02 & 0.06 & 0.10 & \\
\hline TSP & Annual & 0.08 & 0.20 & 0.30 & \\
\hline PM10 & Annual & 0.04 & 0.10 & 0.15 & \multirow{2}{*}{} \\
\hline NOX & Annual & 0.05 & 0.05 & 0.10 & \\
\hline NO2 & Annual & 0.04 & 0.04 & 0.08 & \\
\hline CO & Daily & 4.00 & 4.00 & 6.00 & \multirow{2}{*}{$\mu \mathrm{g} / \mathrm{m}^{3}$} \\
\hline O3 & One hour & 0.12 & 0.16 & 0.20 & \\
\hline LEAD (PB) & Quarterly & 1.5 & $/$ & $/$ & \\
\hline PAP & Annual & 0.01 & $/$ & $/$ & \\
\hline FLUORIDE & Monthly & 1.8 & $/$ & 2.0 & \\
\hline
\end{tabular}

TABLE II: SUMMARY OF AMBIENT AIR QUALITY STANDARDS (GB 3095-2012)

\begin{tabular}{|c|c|c|c|c|}
\hline \multirow[t]{2}{*}{ Pollutant } & \multirow[t]{2}{*}{ Time } & \multicolumn{2}{|c|}{ Values of concentration } & \multirow[t]{2}{*}{ Unit } \\
\hline & & Level 1 & Level 2 & \\
\hline \multirow[t]{3}{*}{$\mathrm{SO}_{2}$} & Annual & 20 & 60 & \multirow{6}{*}{$\mu \mathrm{g} / \mathrm{m}^{3}$} \\
\hline & 24-hour & 50 & 150 & \\
\hline & 1-hour & 150 & 500 & \\
\hline \multirow[t]{3}{*}{$\mathrm{NO}_{2}$} & Annual & 40 & 40 & \\
\hline & 24-hour & 80 & 80 & \\
\hline & 1-hour & 200 & 200 & \\
\hline \multirow[t]{2}{*}{$\mathrm{CO}$} & 24-hour & 4 & 4 & \\
\hline & 1-hour & 10 & 10 & $\mathrm{mg} / \mathrm{m}^{3}$ \\
\hline \multirow[t]{2}{*}{$\mathrm{O}_{3}$} & 8-hour & 100 & 160 & \multirow{15}{*}{$\mu \mathrm{g} / \mathrm{m}^{3}$} \\
\hline & 1-hour & 160 & 200 & \\
\hline \multirow[t]{2}{*}{$\mathrm{PM}_{10}$} & Annual & 40 & 70 & \\
\hline & 24-hour & 50 & 150 & \\
\hline \multirow[t]{2}{*}{$\mathrm{PM}_{2.5}$} & Annual & 15 & 35 & \\
\hline & 24-hour & 35 & 75 & \\
\hline \multirow[t]{2}{*}{ TSP } & Annual & 80 & 200 & \\
\hline & 24-hour & 120 & 300 & \\
\hline \multirow[t]{3}{*}{ NOx } & Annual & 50 & 50 & \\
\hline & 24-hour & 100 & 100 & \\
\hline & 1-hour & 250 & 250 & \\
\hline \multirow[t]{2}{*}{$\mathrm{Pb}$} & Annual & 0.5 & 0.5 & \\
\hline & Quarterly & 1 & 1 & \\
\hline \multirow[t]{2}{*}{$\mathrm{BaP}$} & Annual & 0.001 & 0.001 & \\
\hline & 24-hour & 0.0025 & 0.0025 & \\
\hline
\end{tabular}

The Implementation of the Air Pollution Prevention and Control Action Plan was from 2013 to 2017. The main objective of this Plan was to reduce the concentration of $\mathrm{PM}_{2.5}$ and other air pollutants. Three areas, the Beijing-Tianjin-Hebei region, the Yangtze River Delta region and the Pearl River Delta region, were the focus of the Plan. $\mathrm{PM}_{10}$ needed to be decreased by $10 \%$ compared to with the value in 2012. Meanwhile, for the Beijing-Tianjin-Hebei region, Yangtze River Delta region and Pearl River Delta region, the concentration of $\mathrm{PM}_{2.5}$ would be reduced $25 \%$, $20 \%$ and $15 \%$ respectively, and the concentration of $\mathrm{PM}_{2.5}$ would remain at an annual mean of $60 \mu \mathrm{g} / \mathrm{m}^{3}$ [29]. The Plan implemented regulations, including inter-regional coordination and joint management, elimination of old-fashioned furnaces and inefficient cars, industrial structure adjustment, and clean energy promotion [29].

The Beijing-Tianjin-Hebei and Surrounding Areas Air Pollution Control Action Plan was published in 2013 and focused on Beijing, Tianjin, Hebei, Shanxi, Inner Mongolia and Shandong. This is particularly significant for mitigation of poor air quality in Beijing. The main regulations of the Plan were based on Implementation of the Air Pollution Prevention and Control Action Plan, however, the Plan emphasised and consolidated the importance of inter-regional coordination and joint management. Because pollution transfer is another major contributor to $\mathrm{PM}_{2.5}$ in Beijing The Plan requires Shanxi and Shandong to decrease emissions by $25 \%$, and Inner Mongolia to decrease by $10 \%$, based on levels in 2012 [30].

\section{Benchmarks}

London has undertaken long-term air pollution mitigation and has achieved remarkable results. Monthly values of the concentration of $\mathrm{PM}_{2.5}$ in London from July 2008 to August 2017 basically remain under $25 \mu \mathrm{g} / \mathrm{m}^{3}$, see Fig. 1, which meets the requirements based on The Air Quality Strategy for England, Scotland, Wales and Northern Ireland (Table III). When compared to WHO Air Quality guidelines 2005 for $\mathrm{PM}_{2.5}$ (Table IV), it can be seen that the concentration of $\mathrm{PM}_{2.5}$ in London reaches the interim target-2 (IT-2) [31].

According to Fig. 1, seasonal varieties in the concentration of $\mathrm{PM}_{2.5}$ in Beijing can be seen in selected periods. Normally, the trend is that the higher concentration values occur in winter from November to February every year. In the meantime, the monthly concentration values of

TABLE III: THE AIR QUALITY STRATEGY FOR ENGLAND, SCOTLAND, WALES AND NORTHERN IRELAND

\begin{tabular}{|c|c|c|c|}
\hline \multirow{2}{*}{} & $\begin{array}{c}\text { UK } \\
\text { (except } \\
\text { Scotland) }\end{array}$ & $25 \mu \mathrm{g} / \mathrm{m}^{3}$ & 2020 \\
\cline { 2 - 4 } & Scotland & $12 \mu \mathrm{g} / \mathrm{m}^{3}$ & 2020 \\
\cline { 2 - 4 } $\mathrm{PM}_{2.5}$ & $\begin{array}{c}\text { UK urban } \\
\text { areas }\end{array}$ & $\begin{array}{c}\text { Target of } 15 \% \\
\text { reduction in } \\
\text { concentrations at } \\
\text { urban background. }\end{array}$ & $\begin{array}{c}\text { Between } 2010 \text { and } \\
2020\end{array}$ \\
\hline
\end{tabular}

TABLE IV: WHO AIR QUALITY GUIDELINES AND INTERIM TARGETS FOR PARTICULATE MATTER: ANNUAL MEAN CONCENTRATIONS

\begin{tabular}{|c|c|l|}
\hline $\begin{array}{c}\text { Annual mean } \\
\text { level }\end{array}$ & $\mathrm{PM}_{2.5} \mathrm{\mu g} / \mathrm{m}^{3}$ & \multicolumn{1}{c|}{ Basis for the selected level } \\
\hline $\begin{array}{c}\text { WHO interim } \\
\text { target 1 }\end{array}$ & 35 & $\begin{array}{l}\text { These levels are estimated to be } \\
\text { associated with about 15\% higher } \\
\text { long-term mortality than AQG levels. }\end{array}$ \\
\hline $\begin{array}{c}\text { WHO interim } \\
\text { target 2 } \\
\text { (IT-2) }\end{array}$ & 25 & $\begin{array}{l}\text { In addition to other health benefits, } \\
\text { these levels lower risk of premature } \\
\text { mortality by approximately 6\% } \\
\text { (2-11\%) compared to IT-1. }\end{array}$ \\
\hline $\begin{array}{c}\text { WHO interim } \\
\text { target 3 } \\
\text { (IT-3) }\end{array}$ & 15 & $\begin{array}{l}\text { In addition to other health benefits, } \\
\text { these levels reduce mortality risk by } \\
\text { approximately another 6\% (2-11\%) } \\
\text { compared to IT-2 levels. }\end{array}$ \\
\hline $\begin{array}{c}\text { WHO air } \\
\text { quality } \\
\text { guidelines } \\
\text { (AQG) }\end{array}$ & 10 & $\begin{array}{l}\text { These are the lowest levels at which } \\
\text { total, cardiopulmonary and lung } \\
\text { cancer mortality have been shown to } \\
\text { increase with more than 95\% } \\
\text { confidence in response to PM }\end{array}$ \\
the American Cancer Society's \\
(ACS) study. The use of the PM
\end{tabular}


$\mathrm{PM}_{2.5}$ in Beijing from November 2013 to July 2017 remain within the range of about $40 \mu \mathrm{g} / \mathrm{m}^{3}$ to $130 \mu \mathrm{g} / \mathrm{m}^{3}$. Compared with London's annual mean value for $\mathrm{PM}_{2.5}$, Beijing's values are roughly over four-times higher during the selected periods.

\begin{tabular}{|c|c|c|c|}
\hline $\begin{array}{l}\text { Serial } \\
\text { Number }\end{array}$ & Benchmarking & London & Beijing \\
\hline BM 1 & $\begin{array}{c}\text { Air quality } \\
\text { monitoring network }\end{array}$ & $\begin{array}{l}\text { Widely } \\
\text { allocated }\end{array}$ & Limited \\
\hline BM 2 & $\begin{array}{l}\text { Stringent PM2.5 } \\
\text { requirement }\end{array}$ & $\begin{array}{c}\text { Yes }(\leqslant \\
25 \mu \mathrm{g} / \mathrm{m} 3)\end{array}$ & No $(\leqslant 60 \mu \mathrm{g} / \mathrm{m} 3)$ \\
\hline BM 3 & $\begin{array}{l}\text { Unambiguous legal } \\
\text { provisions }\end{array}$ & $\begin{array}{c}\text { Widely } \\
\text { available }\end{array}$ & Limited \\
\hline BM 4 & $\begin{array}{l}\text { Standards for } \\
\text { vehicles }\end{array}$ & $\begin{array}{c}\text { High } \\
\text { (EURO-VI) }\end{array}$ & $\begin{array}{c}\text { Low } \\
\text { (National-V) }\end{array}$ \\
\hline BM 5 & $\begin{array}{l}\text { Distinct legal } \\
\text { liability }\end{array}$ & $\begin{array}{c}\text { Widely } \\
\text { available }\end{array}$ & Limited \\
\hline BM 6 & $\begin{array}{l}\text { Strict punitive } \\
\text { measures }\end{array}$ & $\begin{array}{c}\text { Widely } \\
\text { available }\end{array}$ & Limited \\
\hline BM 7 & $\begin{array}{c}\text { Congestion charging } \\
\text { scheme }\end{array}$ & $\begin{array}{l}\text { Present ( } £ 11.5 \\
\text { per day) }\end{array}$ & Absent \\
\hline BM 8 & $\begin{array}{c}\text { Open and } \\
\text { transparent air } \\
\text { pollution } \\
\text { information to the } \\
\text { public }\end{array}$ & $\begin{array}{c}\text { Widely } \\
\text { available }\end{array}$ & Limited \\
\hline BM 9 & $\begin{array}{l}\text { Active public } \\
\text { participation }\end{array}$ & High & Low \\
\hline BM 10 & $\begin{array}{l}\text { Promotion of clean } \\
\text { energy vehicles }\end{array}$ & $\begin{array}{c}\text { Widely } \\
\text { available }\end{array}$ & Limited \\
\hline BM 11 & $\begin{array}{l}\text { Development of } \\
\text { energy efficient } \\
\text { buildings }\end{array}$ & $\begin{array}{c}\text { Widely } \\
\text { available }\end{array}$ & Limited \\
\hline
\end{tabular}

Table $\mathrm{V}$ presents benchmarking criteria based on the data collection of two cities. It can be seen that London achieved significant changes on $\mathrm{PM}_{2.5}$ and attained notable performance compared to Beijing.

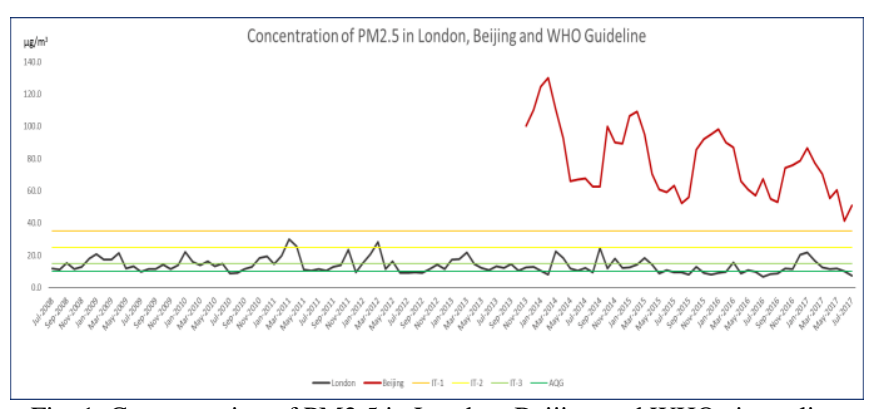

Fig. 1. Concentration of PM2.5 in London, Beijing and WHO air quality guideline.

\section{DISCUSSION}

\section{A. Weaknesses in Beijing's PM2.5 Mitigation}

1) Insufficient understanding of causes and sources of PM2.5 (BM1, BM2)

Although the central government and Beijing government have endeavoured to improve air pollution levels in Beijing, there are many challenges in air pollution mitigation governance. It is insufficient to simply understand the causes and sources of $\mathrm{PM}_{2.5}$ in Beijing [32]. Haze pollution has been taking place over the past 15 years. However detailed research on causes and sources of $\mathrm{PM}_{2.5}$ only started a few years ago. $\mathrm{PM}_{2.5}$ was first officially catalogued into the Ambient Air Quality Standard and added to air pollution monitoring in 2012. Beijing established 35 monitoring stations in 2012 but the majority of cities in China did not have a monitoring network until 2013 [33]. This means that people did not know how much $\mathrm{PM}_{2.5}$ came from local industry and transport and how much $\mathrm{PM}_{2.5}$ came from trans-boundary pollution. There is no support to effectively manage regional $\mathrm{PM}_{2.5}$. In the meantime, the requirement for $\mathrm{PM}_{2.5}$ concentration is much lower than London.

2) Incomplete air pollution legislation framework (BM3, BM4)

The Chinese legislative framework is incomplete and lagging behind other nations. Over the past 40 years, there have been eight laws and regulations regarding environment protection and air pollution control in Beijing, and four of them were enacted and clarified $\mathrm{PM}_{2.5}$ in the last five years. However, the influence of $\mathrm{PM}_{2.5}$ in Beijing can be traced back to 2000. Between 2001 and 2012, there was no long-term targeted and effective legislation framework to control $\mathrm{PM}_{2.5}$ [34]. Although the Ambient Air Quality Standards (GB3095-2012) explicitly set up $\mathrm{PM}_{2.5}$ requirements, the corresponding laws and regulations were delayed until subsequent years.

Additionally, articles in the laws regarding $\mathrm{PM}_{2.5}$ mitigation have less operability because some of them lack exact requirements or instructions, which means that the laws are flexible and make it difficult to enact actual mitigation practices. Moreover, the Implementation of the Air Pollution Prevention and Control Action Plan, for example, merely directs $\mathrm{PM}_{2.5}$ concentration and implements limitation on emissions in the specified major cities instead of the whole nation [35].

Furthermore, laxer regulations and lower requirements for vehicle emissions are another problem. Although Beijing has carried out National-V standards, which basically equals the Euro 5 emission standard, lower requirements had been applied for a long time before National-V standards were implemented [36].

\section{3) Ambiguous Legal Liability (BM5)}

Ambiguous legal liability leads to inefficient $\mathrm{PM}_{\mathbf{2 . 5}}$ mitigation. In the laws related to environmental protection, there are many articles that are too general to define responsibilities in a clear way [37]. As a result, relevant departments shirk their responsibilities and shift the blame onto others. For example, the Ministry of Environmental Protection has supervisory powers but no enforcement powers; in contrast the Public Security Bureau is entitled to enforcement powers [35].

Furthermore, the mechanism of accountability is limited. The Chinese government, Beijing government and other local governments should be responsible for bad air quality due to poor management. As city administrations, their duties 
are to protect the environment and provide a healthy living environment for all. However, due to deficiencies in the air quality management plans, bureaucracy, and intertwined economic interests, the performance of environmental governance is always unsatisfactory [38].

\section{4) Inefficient law enforcement (BM6, BM7)}

Law enforcement is another crucial challenge in $\mathrm{PM}_{\mathbf{2 . 5}}$ mitigation. There are two key problems leading to inefficient law enforcement. One is no strict punitive measures. Generally, low or medium scale air pollution would be considered as civil cases and the responsible person only needs to pay penalties for compliance violations without incurring a prison sentence [39]. The other problem is the low level of fine. Before the latest Environmental Protection Law was implemented, the maximum fine for an environment pollution issue was $¥ 500,000$ (about AU\$100,000). Many enterprises accept fines rather than complying with the laws when pursuing maximum profits because the fine is much less than their profits. The latest Environmental Protection Law has amended punitive measures, for example the new fine is imposed on infringements on a calendar day basis and therefore increases as the time goes on.

Additionally, encouraging economic development is a basic state policy. As a result, local governors attach their careers to local economic development at the expense of damaging the environment. Local protectionism also leads to inefficient law enforcement [38].

Moreover, millions of oil-burning vehicles are on the roads every day, which congests roads and produces massive amounts of pollutants in the city. However, the Beijing government has not formulated a proper policy, such as a congestion charging scheme, to mitigate this burden [40].

\section{5) Less public participation (BM8, BM9)}

There is less public participation and public interest litigation regarding $\mathrm{PM}_{2.5}$ mitigation in Beijing than in other cities such as London. In many developed nations, public participation and public interest litigation are active behaviours for environmental protection, as well as promoting governments' environmental governance [41]. Hence, they are very popular within developed nations, and governments also positively encourage people to get involved. For example, in the Mayor's Air Quality Strategy 2010, the London Council acted positively to bring public participation into line with the regional plan. In the meantime, citizens have considerable access to public interest litigation.

On the contrary, in Beijing, the penetration of public participation and public interest litigation is low because of two main reasons. Subjectively, citizens' environmental awareness remains at a low level. Most citizens believe that $\mathrm{PM}_{2.5}$ mitigation is the duty of the government, and they have not realised that air quality would directly influence their living standards [42]. For instance, despite worsening air quality, the number of cars on Beijing's roads is increasing every year. Objectively, the governments lack relevant laws and regulations to support public participation. In some laws related to environmental protection, public interest litigation is mentioned, however, there is no specific guidance and access to public interest litigation.

\section{6) Poor energy efficiency promotion (BM10, BM11)}

Green cars and energy efficient buildings are promoted in London because they would contribute significantly to air pollution reduction. However, In Beijing, there is a lack of incentive to support low carbon life. During the period from November to February in Beijing heating is required by most residents. This is an issue which results in high concentrations of $\mathrm{PM}_{2.5}$. Most of the buildings in Beijing are not energy efficient with poor heating insulation, which leads to high energy consumption and considerable emissions overall [43].

\section{B. Improvements for Beijing Air Pollution Mitigation Governance}

Inter-regional coordination and joint management is an effective approach which has been examined as a suitable method for Beijing $\mathrm{PM}_{2.5}$ mitigation [35]. During the 2008 Beijing Olympic Games, as a short-term policy, inter-regional coordination and joint management played important roles in $\mathrm{PM}_{2.5}$ control. During that period, not only did the Beijing government take actions but also the surrounding municipalities and provinces, Hebei, Shandong, Inner Mongolia and Shanxi. They concurrently took action to improve local air quality to guarantee Beijing good air quality for the Olympics [44]. The core concept of this policy was to treat Beijing and its surrounding areas as a single unit, and collaboratively manage air quality [45]. Specifically, the policy required heavy industries to install flue-gas desulfurisation (FGD), and shut down high energy consumption and heavily-polluting plants if they could not meet the requirements within the appointed time. Meanwhile, the policy strictly eliminated old vehicles, and established a vehicle restriction scheme for even and odd-numbered license plates on alternate days from July to September in Beijing [46]. However, after the event, inter-regional coordination and joint management was not uniformly maintained leading to levels of pollution reverting to their former state.

In 2013, inter-regional coordination and joint management was written into the Implementation of the Air Pollution Prevention and Control Action Plan and consolidated by the Law on Air Pollution Prevention and Control. Zhuang, Zhou and Bo [11] claimed that inter-regional coordination and joint management would achieve great progress in the reduction of $\mathrm{PM}_{2.5}$ in Beijing if local governments improved aspects of legislative frameworks and law enforcement and invoked stringent requirements for vehicles and fuel type, encouraged public participation and reduced traffic congestion.

\section{1) Legislative framework improvement}

The legislative framework can be regarded as one of the most fundamental approaches in $\mathrm{PM}_{2.5}$ mitigation. Based on understandings of mitigation experiences in London and the situation in Beijing, the legislative framework can be further improved for responding to the issue of $\mathrm{PM}_{2.5}$.

Firstly, a regional legislative framework can be developed based on the mechanism of regional air management. The Beijing government should collaborate with surrounding local governments to establish a regional legislative framework for cross-regional air quality management [47]. 
The framework could be derived from the Law on Air Pollution Prevention and Control, and take the regional situations into account for developing more suitable frameworks to cope with $\mathrm{PM}_{2.5}$. For example, particular rules and regulations can be formulated based on the Environmental Protection Law 2015 and the Law on Air Pollution Prevention and Control 2016 for the regional government. Detailed explanatory rules are beneficial for the Beijing government and relevant regional governments to enact mitigation policies.

Secondly, based on the Law on Air Pollution Prevention and Control 2016, specific regulations can be respectively established in Beijing and its surrounding areas for major pollution sources, such dust, exhaust fumes and industrial emissions, in order to build a comprehensive legislative network for regulation of $\mathrm{PM}_{2.5}$. Various emissions should comply with corresponding regulations, which would greatly improve when the legislative framework is implemented [48].

\section{2) Joint administrative department establishment for efficient law enforcement and distinct liability}

The Beijing government should probably cooperate with surrounding local governments to establish a specific joint administrative department empowered to manage the most important issues related to air quality within the region [49]. Within Beijing and its surrounding regions, to achieve efficient law enforcement, a joint administrative department would integrate the Ministry of Environmental Protection and Public Security Bureau to supervise, investigate and penalise those who break environmental laws [11]. The department would have the power to impose significant fines and send offenders to jail.

The department should also be able to assess the environmental impacts of heavy industries in Beijing and the surrounding regions. If the industrial plants cannot meet environmental standards, the department should require them to make rectifications within a fixed period of time and update their improvement plan from time to time when required [47].

To clear liability and avoid bureaucracy, the department needs to establish a long-term mechanism to review local air quality regularly, constantly adjust the air quality governance strategy, and recurrently amend local $\mathrm{PM}_{2.5}$ mitigation policies. It also needs self-review from time to time to ensure improvements [48]. The core of this specific joint administrative department is that it integrates several departments to manage air quality and becomes more efficient in the process.

\section{3) Stringent requirements for vehicles and fuel}

Many scholars believe that low standards and requirements for vehicle emissions and vehicle fuel are the major reasons leading to high concentration of $\mathrm{PM}_{2.5}$ [48]. To achieve great progress on $\mathrm{PM}_{2.5}$ reduction, upgrading standards and requirements is essential in Beijing and its surrounding areas.

National-V standards for new cars have been implemented in Beijing since 2013 [50]. Compared to National-IV standards, the National-V standards require nitrogen oxides to be reduced $25 \%$ and $43 \%$ for light vehicles and heavy vehicles respectively [36]. However, National-V standards are only for new cars that were sold after 2013. Therefore, the central government, Beijing and surrounding regional governments must promote National-V standards for all cars. Moreover, for those cars with National-III and National-IV standards, it should be mandatory to install vehicle exhaust filters to achieve the latest requirements for all vehicles used in the Beijing area [51]. For those old cars with fairly low emission standards, like 'Yellow Label' cars, which indicates that they may emit up to ten to fifty times higher concentrations of pollutants than more modern cars, the governments must ensure that these are entirely eliminated [52].

Additionally, more stringent testing of vehicles must be implemented by Beijing and the surrounding regional governments for new cars coming onto the market [52]. The governments need to take actions to review the process of automobile manufacturing, and vehicle producers must provide all verification of conformity. At the same time, third party testing organisations should be introduced similar to those in the UK. For those cars on the roads, the governments need to establish a mobile testing network for on-the-spot checks. Moreover, vehicle monitoring equipment needs to be gradually installed in cars for real-time data collection.

The quality of vehicle fuel also needs to be improved. According to Yang and Liu [39], low quality fuel is one of the biggest problems hampering the reduction of $\mathrm{PM}_{2.5}$ Compared with advanced countries, China's fuel quality is at a low level. If the sulphur content can be reduced to $0.1 \%$ by mass, pollution levels would be reduced dramatically [52]. Vehicle fuel producers are currently involved in fuel standards formulation. It is obvious that these intertwined interests impede improvement of fuel quality to some extent. Therefore, the Chinese government and local governments, especially that of Beijing, should take action to prevent vehicle fuel producers from involvement in fuel standards formulation, and establish subsequently objective standards.

\section{4) Public participation and public interest litigation}

Public participation and public interest litigation are important parts in environment protection. Involvement in these two behaviours not only protects basic human rights, but also promotes the development of environmental protection.

Public participation and public interest litigation were written into the Law on Air Pollution Prevention and Control 2016. However, this has not significantly activated people's participation in Beijing and surrounding regions [49]. Hence, governments need to formulate particular regulations to support public participation. For example, the governments actively promote "low-carbon life" and set up a "green fund" for communities. Environmental protection and "low-carbon life" could be introduced in compulsory education to formulate the importance of environmental awareness in the minds of young people.

Public interest litigation lags behind more developed countries. Beijing and its surrounding regional governments should enact detailed regulations to encourage people to protect basic human rights. Additionally, the governments should provide free legal help and consultancy services [47]. Moreover, typical cases of public interest litigation could be regularly advertised and learned which would encourage people to be more aware of the environmental issues. 


\section{5) Air quality monitoring network improvement}

A complete air quality monitoring network provides sufficient and comprehensive data for policy-makers to formulate strategies to improve the state of the environment. Because of an insufficient air quality monitoring network in the early period, Beijing could not accurately measure the components in the pollutants, which resulted in less understanding of $\mathrm{PM}_{2.5}$ [47]. Although an increasing number of monitoring stations have been constructed in Beijing, in surrounding regions there is still a low level of monitoring. Therefore, it is important to urgently develop an air quality monitoring network surrounding Beijing [35]. Moreover, appropriate physical placement for monitoring stations is extremely important. Normally, the concentration of $\mathrm{PM}_{2.5}$ in rural areas is lower than in the city. If the monitoring stations cannot be sited appropriately, it would directly affect the monitoring results [8].

\section{6) Traffic improvement}

Automobile exhaust gas is one of the biggest pollutant sources in Beijing. It is estimated that there will be at least 6 million vehicles in Beijing by the end of 2017 [53]. The Beijing government therefore should take actions immediately to improve the urban traffic situation. A number of relatively useful actions could be taken without too much intervention and have been shown to work in the past, such as during the Olympics [46].

The "odd-even" traffic restrictions are currently implemented in the centre of Beijing, which aims to reduce urban traffic pressures and reduce air pollution. The restrictions probably help reduce $\mathrm{PM}_{2.5}$ to some extent, but as an intermittent policy, it does not effectively deal fully with $\mathrm{PM}_{2.5}$ pollution.

As a consequence of the continuing emission issue, a congestion charging scheme should be implemented in Beijing. Such a scheme would follow the example of the system implemented in London to tackle urban traffic congestion. The implementation has had impressive results, therefore Beijing could enact a similar scheme to reduce the current problems [42].

Efficient public transport plays an important role in releasing traffic pressure. At present, there are 19 subways lines and hundreds of bus routes in Beijing, which transport millions of people living in Beijing. The Beijing government should invest more funds to upgrade to clean energy buses and maximise the function of public transport and increase its popularity among all residents.

\section{7) Low carbon life promotion}

Green vehicles, such as electric cars should be promoted in Beijing and its surrounding areas. It would be beneficial for the governments to provide subsidies for those who buy green vehicles and the manufacturers who produce them [54] Electric charging sites also need to be widely constructed to guarantee the use of green cars. Lack of charging sites can act as a deterrent for the use of electric vehicles, therefore access to such sites, and their efficient placement needs to be considered essential.

Energy-efficient buildings aim to reduce energy consumption and increase energy efficiency in buildings of all sorts. In Britain, energy-efficient buildings help reduce total carbon emissions by $20 \%$ in 2010 [55]. The British government established the Energy Performance Certificate (EPC) to describe the level of energy efficiency of a building and include a range of measurements from A (Very energy efficient) to $G$ (Not energy efficient). As a considerable amount of redevelopment is taking place in Beijing, the Beijing government should gradually formulate a policy to support the development of energy-efficient buildings as a long-term strategy.

\section{CONCLUSION}

This study benchmarked air pollution and its management in Beijing. While significant effects have been made by the Beijing government and improvements in air quality have been achieved, there has been only a slightly decreasing trend of $\mathrm{PM}_{2.5}$ concentration in Beijing, which means that the improvements the government made have taken minimal effect on air pollution reduction; consequently, there is significant progress still to be made. This study details a number of actions based on inter-regional coordination and joint management that can be developed to further improve air pollution. Beijing and its surrounding regional governments' air pollution mitigation governance should be considered as complementary to nation-wide ones. Furthermore, local $\mathrm{PM}_{2.5}$ mitigation approaches can be spread to national level if they are able to achieve great performance. Obviously, if dual $\mathrm{PM}_{2.5}$ mitigation policies, top-down and bottom-up, can be effectively implemented, China and Beijing would achieve significant progress on $\mathrm{PM}_{2.5}$ mitigation but achieving the air quality levels of London will require significant investment. It is important for the Chinese national government and the local Beijing government to realise that clean air is a right for all citizens and follow the example of other cities such as London where air pollution management has achieved significant progress.

\section{REFERENCES}

[1] World Health Organization. (2014). 7 million premature deaths annually linked to air pollution. [Online]. Available: http://www.who.int/mediacentre/news/releases/2014/air -pollution/en/

[2] X. Zhao, X. Yu, Y. Wang, and C. Fan, "Economic evaluation of health losses from air pollution in Beijing," China Environ. Sci. and Pollut. Res., vol. 23, pp. 11716-28, 2016.

[3] D. L. Davis, "A look back at the London smog of 1952 and the half century since," Envir. Health Perspectives, vol. 110, pp. A734-A735, 2002.

[4] M. Williams, "Air pollution and policy-1952-2002," Sci. of the Total Environ., vol. 334, pp. 15-20, 2004.

[5] D. W. Dockery, "Health effects of particulate air pollution," Ann Epidemiol, vol. 19, pp. 257-263, 2009.

[6] D. M. Elsom and J. Longhurst, "Assessment of the first phase of the UK national air quality strategy," WIT Transactions on Ecology and the Envir., vol. 21, pp. 15-24, 1997

[7] Greenpeace. (2013). The health impacts of power plants in Jingjinji. [Online]. Available: http://www.greenpeace.org/eastasia/publications/reports/climate-ener gy/ 2013/health-impacts-coal-power/

[8] L. Yu, G. Wang, R. Zhang, L. Zhang, Y. Song, B. Wu, X. Li, K. An, and J. Chu, "Characterization and source apportionment of $\mathrm{PM}_{2.5}$ in an urban environment in Beijing," Aerosol and Air Quality Res., vol. 13 , pp. 574-583, 2013.

[9] G. He, Y. Lu, A. P. Mol, and T. Beckers, "Changes and challenges: China's environmental management in transition," Environ. Development, vol. 3, pp. 25-38, 2012. 
[10] Q. Zhang, K. He, and H. Huo, "Policy: Cleaning China's air,” Nature, vol. 484, pp. 161-162, 2012.

[11] G. X. Zhuang, W. Z. Zhou, and F. Bo, "Theoretical basis and innovative mechanism for collaborative governance on haze around Beijing-Tianjin-Hebei region," J. of China Uni. of Geosci. (Soci. Sci. Edition), vol. 17, pp. 10-17, 2017.

[12] Y. F. Jarrar and M. Zairi, "Future trends in benchmarking for competitive advantage: A global survey," Total Quality Management, vol. 12, pp. 906-912, 2001.

[13] G. MacKerron and S. Mourato, "Life satisfaction and air quality in London," Ecol. Econ, vol. 68, pp. 1441-53, 2009.

[14] P. Brimblecombe, "The clean air act after 50 years," Weather, vol. 61, pp. 311-14, 2006.

[15] S. Mosley. (2017). Clearing the air: Can the 1956 clean air act inform new legislation. [Online]. Available: http://www.historyandpolicy.org/policy-papers/papers/clearing-the-air -can-the-1956-clean-air-act-inform-new-legislation

[16] Clean Air Act 1956 Chapter 52. [Online]. Available: http://www.legislation.gov.uk/ukpga/Eliz2/4-5/52/enacted

[17] United Kingdom Atomic Energy Authority, AEA Technology Environment Report 2002, AEA London, 2002.

[18] Clean Air Act 1968 Chapter 62. [Online]. Available: http://www.legislation.gov.uk/ukpga/1968/62/contents/enacted

[19] S. Sorrell, "The meaning of BATNEEC: interpreting excessive costs in up industrial pollution regulation," J. of Environ. Policy \& Planning, vol. 4, pp. 23-40, 2002.

[20] Clean Air Act 1993 Chapter 11. [Online]. Available: https://www.legislation.gov.uk/ukpga/1993/11/contents

[21] Environment Act 1995 Chapter 25. [Online]. Available: https://www.legislation.gov.uk/ukpga/1995/25/contents

[22] Department for Environment Food and Rural Affairs, The Air Quality Strategy for England, Scotland, Wales and Northern Ireland, London, 2007.

[23] Pollution Prevention and Control Act 1999 Chapter 24. [Online]. Available:

https://www.legislation.gov.uk/ukpga/1999/24/pdfs/ukpga_19990024 _en.pdf

[24] Greater London Authority, Mayor's Air Quality Strategy, London, 2010.

[25] Y. B. Bai, "To get ready for implementing the new environmental protection law for promoting environmental protection perfectly," Environment and Sustainable Development, vol. 112, pp. 137-9, 2015

[26] Environmental Protection Law 2015. [Online]. Available: http://zfs.mep.gov.cn/fl/201404/t20140425_271040.htm

[27] Law on Air Pollution Prevention and Control 2000. [Online]. Available: http://www.gdep.gov.cn/zcfg/falv/201008/t20100809_82365.html

[28] Beijing Environmental Protection Bureau. (2015). Contributors of PM2.5 in Beijing. [Online]. Available: http://www.bjepb.gov.cn/bjepb/323474/331443/331937/333896/3961 91/index.html

[29] Implementation of the Air Pollution Prevention and Control Action Plan 2013. [Online]. Available: http://www.gov.cn/zwgk/2013-09/12/content_24867 73.htm

[30] Ministry of Environmental Protection. (2013). Jingjinji and Surrounding Areas Air Pollution Control Action Plan. [Online] Available: http://www.gov.cn/zwgk/201309/12/content_2486773.htm

[31] World Health Organization, "WHO air quality guidelines for particulate matter, ozone, nitrogen dioxide and sulfur dioxide," WHO Geneva Switzerland, 2005.

[32] B. Lv, B. Zhang, and Y. Bai, "A systematic analysis of $\mathrm{PM}_{2.5}$ in Beijing and its sources from 2000 to 2012," Atmos. Environ., vol. 124, pp. 98-108, 2016.

[33] X.G. Liu, J. Li, Y. Qu, T. Han, L. Hou, J. Gu, C. Chen, Y. Yang, X. Liu, T. Yang, and Y. Zhang, "Formation and evolution mechanism of regional haze: a case study in the megacity Beijing, China," Atmo. Chem. Phys., vol. 13, pp. 4501-14, 2013.

[34] B. Xue, B. Mitchell, Y. Geng, W. Ren, K. Müller, Z. Ma, J. A. P Oliveira, T. Fujita, and M. Tobias, "A review on China's pollutant emissions reduction assessment," Ecol. Indic. vol. 38, pp. 272-8, 2014

[35] H. Zhang, S. Wang, J. Hao, X. Wang, S. Wang, F. Chai, and M. Li, "Air pollution and control action in Beijing, "J Clean Prod, vol. 112, pp. 1519-27, 2016.

[36] S. Yu, "The quality and pollution of China's Fuel," Ecol. Econ. vol. 31, pp. 10-13, 2015
[37] K. M. Zhang and Z. G. Wen, "Review and challenges of policies of environmental protection and sustainable development in China," $J$ Environ Manage., vol. 88, pp. 1249-61, 2008.

[38] X. Zhang and J. Liang, "From London to Beijing: A comparison and reflexion on smog controls in Britain and China," Frontiers, vol. 2, pp. $51-63,2014$

[39] C. Yang and W. J. Liu, "On the governance dilemma and countermeasures of controlling haze," Environment and Sustainable Development, vol. 2, pp. 68-71, 2016.

[40] M. Liu, J. Zhu, and B. Mao, "London congestion charging experience and its implications for Beijing," J. Trans. Sys. Eng. and Info. Tech., vol. 1, pp. 146-151, 2011.

[41] J. Newman, M. Barnes, H. Sullivan, and A. Knops, "Public participation and collaborative governance," J. Soc. Policy, vol. 33, pp. 203-23, 2004

[42] J. Xie, J. S. Huang, and Y. Wang, "Research on netizens' environmental awareness in China based on the web survey data: drive or not on a hazy day," China Population, Resources and Environment, vol. 25, pp. $377-81,2015$.

[43] J. Li, "Towards a low-carbon future in China's building sector - A review of energy and climate models forecast," Energy Policy, vol. 36 , pp. 1736-47, 2008

[44] J. Wang J, M. Ning, and Y. Sun, "Study on theory and methodology about joint prevention and control of regional air pollution," Environment and Sustainable Development, vol. 5, pp. 5-10, 2012.

[45] Y. Chen, G. Z. Jin, N. Kumar, and G. Shi, "The promise of Beijing: Evaluating the impact of the 2008 Olympic Games on air quality," Journal of Environmental Economics and Management, vol. 66, pp. 424-43, 2013.

[46] X. Wang, D. Westerdah, L. C. Chen, Y. Wu, J. Hao, X. Pan, X. Guo, and K. M. Zhang, "Evaluating the air quality impacts of the 2008 Beijing Olympic Games: On-road emission factors and black carbon profiles," Atmos. Environ., vol. 43, pp. 4535-43, 2009.

[47] Y. Li, L. H. Wang, J. Ma, and C. Ge, "Research on coordination mechanism of joint prevention and control of air pollution in Beijing-Tianjin-Hebei," J. China Uni.of Geosci., vol. 17, pp. 45-50, 2017.

[48] W. X. Wei and X. L. Ma, "Optimal policy for energy structure adjustment and haze governance in China," China Population, Resources and Development, vol. 25, pp. 6-14, 2015.

[49] L. Yan, J. Y. He, X. Wang, and Z. Ding, "Discussion about regional air pollution joint prevention and control mechanism in China,' Environment and Sustainable Development, vol. 5, pp. 30-33, 2016.

[50] Ministry of Environmental Protection, (2016). Notice on the implementation of the fifth stage vehicle emission standard. [Online]. Available: http://www.mep.gov.cn/gkml/hbb/bgg/201601/t20160118_326596.ht $\mathrm{m}$

[51] Y. Zhang and L. He, "Haze mitigation in Beijing," Ecol. Econ., vol. 32 , pp. 10-13, 2016.

[52] K. Yang, Z. Xia, F. He, L. Wu, and L. Gong, "Correlation of fuel quality and emissions of motor vehicle with atmospheric pollution in Beijing," Environment and Sustainable Development, vol. 34, pp. 304-17, 2017.

[53] R. Han, B. Y. Yu, B. J. Tang, H. Liao, and Y. M. Wei, "Carbon emissions quotas in the Chinese road transport sector: A carbon trading perspective," Energy Policy, vol. 106, pp. 298-309, 2017.

[54] Z. Q. Sun and M. Liu, "Analysis of legal regulation on haze pollution in China," Environmental Science and Management, vol. 4, pp. 13-17, 2016.

[55] I. G. Hamilton, P. J. Steadman, H. Bruhns, A. J. Summerfield, and R. Lowe, "Energy efficiency in the British housing stock: Energy demand and the homes energy efficiency database," Energy Policy, vol. 60, pp $462-480,2013$

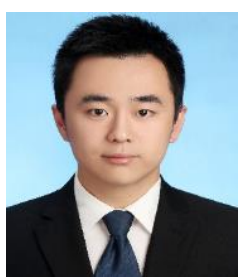

Daohan Tang is originally from China. Mr. Tang received his master's degree in environmental management from Flinders University, South Australia in December 2017. Mr. Tang intends to apply for a Ph.D program in the relative study field Mr. Tang published an article named "China's wind development" on the $20183^{\text {rd }}$ International Conference on Advances in Energy and Environment Research, and attended the $20186^{\text {th }}$ International Conference on Environment Pollution and Prevention. Currently, Mr. Tang is studying on the policies related to climate change adaption and mitigation. 